Vol. 14 (2005): 24-33.

\title{
Hydrochemistry of rivers in an acid sulphate soil hotspot area in western Finland
}

\author{
Marcus Roos \\ Department of Geology and Mineralogy, Åbo Akademi University, FI-20500 Åbo, Finland. \\ Present address: Department of Biology and Environmental Science, Kalmar University, SE-39182 Kalmar, Sweden, \\ e-mail:marcus.roos@hik.se \\ Mats Åström \\ Department of Biology and Environmental Science, Kalmar University, SE-39182 Kalmar, Sweden
}

During heavy rains and snow melting, acid sulphate (AS) soils on the coastal plains of Finland are flushed resulting in discharge of acidic and metal-rich waters that strongly affect small streams. In this study, the impact of AS soils occurrence and hydrological changes on water quality were determined for 21 rivers (catchment sizes between $96-4122 \mathrm{~km}^{2}$ ) running through an AS soil hotspot area in western central Finland. Water samples, collected at the outlet, during eight selected events, were analysed for $\mathrm{pH}$, dissolved organic carbon, electrical conductivity (EC) and 32 chemical elements. Based on the correlation with percentage arable land in the catchments (a rough estimate of AS soil occurrences, as up to $50 \%$ of the arable land is underlain with these soils), it was possible to categorize variables into those that are enriched in runoff from such land, depleted in runoff from such land (only one element), and not affected by land-use type in the catchments. Of the variables enriched in runoff from arable land, some were leached from AS soils during high-water flows, in particular (aluminium, boron, beryllium, cadmium, cobalt, copper, lithium, manganese, nickel, sulphur, silicon, thorium, thallium, uranium, and zinc) and others occurred in highest concentrations during lower flows (calcium, EC, potassium, magnesium, sodium, rubidium and strontium). Molybdenum and phosphorus were not leached from AS soils in larger amounts than from other soils and thus related to other factors connected to the arable land. Based on the concentrations of potentially toxic metals derived from AS soils, the 21 rivers were ranked from the least (Lestijoki River, Lapväärtinjoki River and Perhonjoki River) to the most (Sulvanjoki River, Vöyrinjoki River and Maalahdenjoki River) heavily AS soil impacted. It has been decided that Vöyrinjoki is to be dredged along a ca. $20 \mathrm{~km}$ distance. This is quite alarming considering the high metal concentrations in the river.

Key words: acid sulphate soil, hydrochemistry, hydrograph, Finnish rivers, toxic metals 
Vol. 14 (2005): 24-33.

\section{Introduction}

Acid sulphate (AS) soils cause, in adjacent surface waters, high concentrations of sulphuric acid $(\mathrm{pH}$ minimum $<3.0$ ) and many potentially toxic ele-

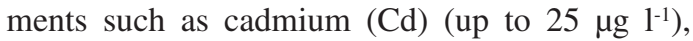
nickel (Ni) (1 $\left.200 \mu \mathrm{g} \mathrm{l}^{-1}\right)$, zinc (Zn) $\left(2500 \mu \mathrm{g} \mathrm{l}^{-1}\right)$, cobalt (Co) $\left(700 \mu \mathrm{g}^{-1}\right)$, aluminium (Al) (300 000 $\left.\mu \mathrm{g}^{-1}\right)$, manganese $(\mathrm{Mn})\left(120000 \mu \mathrm{g} \mathrm{l}^{-1}\right)$ and thallium (Tl) $\left(0.4 \mu \mathrm{g} \mathrm{l}^{-1}\right)$ (Åström and Spiro 2000, Åström 2001a). This leads to, as e.g. Sundström et al. (2002) roughly estimated for the AS soil occurrences in central western Finland, an annual discharge to the water environment of, among others, 80 tons $\mathrm{Ni}$ and 40 tons $\mathrm{Co}$. This is in the magnitude of ten times more than the corresponding discharge from the entire Finnish industry. The inevitable result of this stress is extensive and serious hydrobiological damage (Kjellman and Hudd 1996, Hudd 2000).

In addition to the AS soil occurrences in Finland, which are the largest in Europe, these soils exists in Sweden and worldwide they are common in Australia, South East Asia and Africa (Ritsema et al. 2000). Wherever these soils are found the hydrological/chemical mechanisms which give rise to environmental problems are similar: when the waterlogged sediments (usually Holocene) once deposited in the ocean are drained (ditching, drainage for exploitation/roadwork etc), the inherent sulphide minerals are oxidised leading to the release and mobilisation of acid and toxic metals (Wiklander et al. 1950, Purokoski 1959, van Breemen 1973, Dent 1980, Lowson 1982). The underlying mechanism is consequently natural, while the trigger almost always is human activities.

On the coastal plains of western central Finland, there is an AS soil hotspot area, i.e. an area where these soils are particularly abundant (Palko 1994, Yli-Halla et al. 1999) and cause serious environmental problems. Although several studies carried out in this area show that small ditches are greatly affected by AS soils, i.e. have low $\mathrm{pH}$ and high metal concentration (Palko and Yli-Halla 1993, Weppling 1993, Edén et al. 1999), the impact on the larger and biologically important rivers has not been adequately investigated. A few studies focusing on a single river exist (Åström and Åström 1997, Edén et al. 1999, Åström 2001b, Roos and Åström 2005), but studies covering and comparing several rivers at the same time are rare (Weppling 1993). The aim of this study was to investigate the hydrochemistry of all the rivers in this area and to rank them from the least to the most affected by this environmentally unfriendly soil type.

\section{Material and methods}

\section{Water sampling}

Twenty-one rivers which empty into the Gulf of Bothnia were studied (Fig. 1). They were sampled as close as possible to the sea at sites where there were no risk of sea water contamination. The sampling was undertaken eight times during the course of two years, with the intention to sample: (1) high flow caused by snowmelt during spring, (2) low flow caused by summer heat and vegetation, and (3) high flow caused by autumn rain. While we succeeded with "1" (April 2002 and 2003) and "2" (July and September 2002), our third intention did not succeed due to extremely dry autumns both sampling years (Fig. 2). This draught was the result of very little rainfall during the time period of August-December 2002 and July-November 2003. Three sampling events were however carried out during autumn (October/November 2002 and November 2003) but all at low flows (Fig. 2). Consequently, the study additionally gave an insight into how AS soils affect the rivers during, for the area, extremely dry autumn periods.

The hydrograph is determined daily for 12 of the rivers (Lestijoki River, Kälviänjoki River, Perhonjoki River, Kruunupyynjoki River, Ähtävänjoki River, Lapuanjoki River, Kyrönjoki River, Laihianjoki River, Maalahdenjoki River, Närpiönjoki River, Teuvanjoki River and Lapväärtinjoki River) by Regional Environment Centres. Since the nine unmeasured rivers have a similar topogra- 


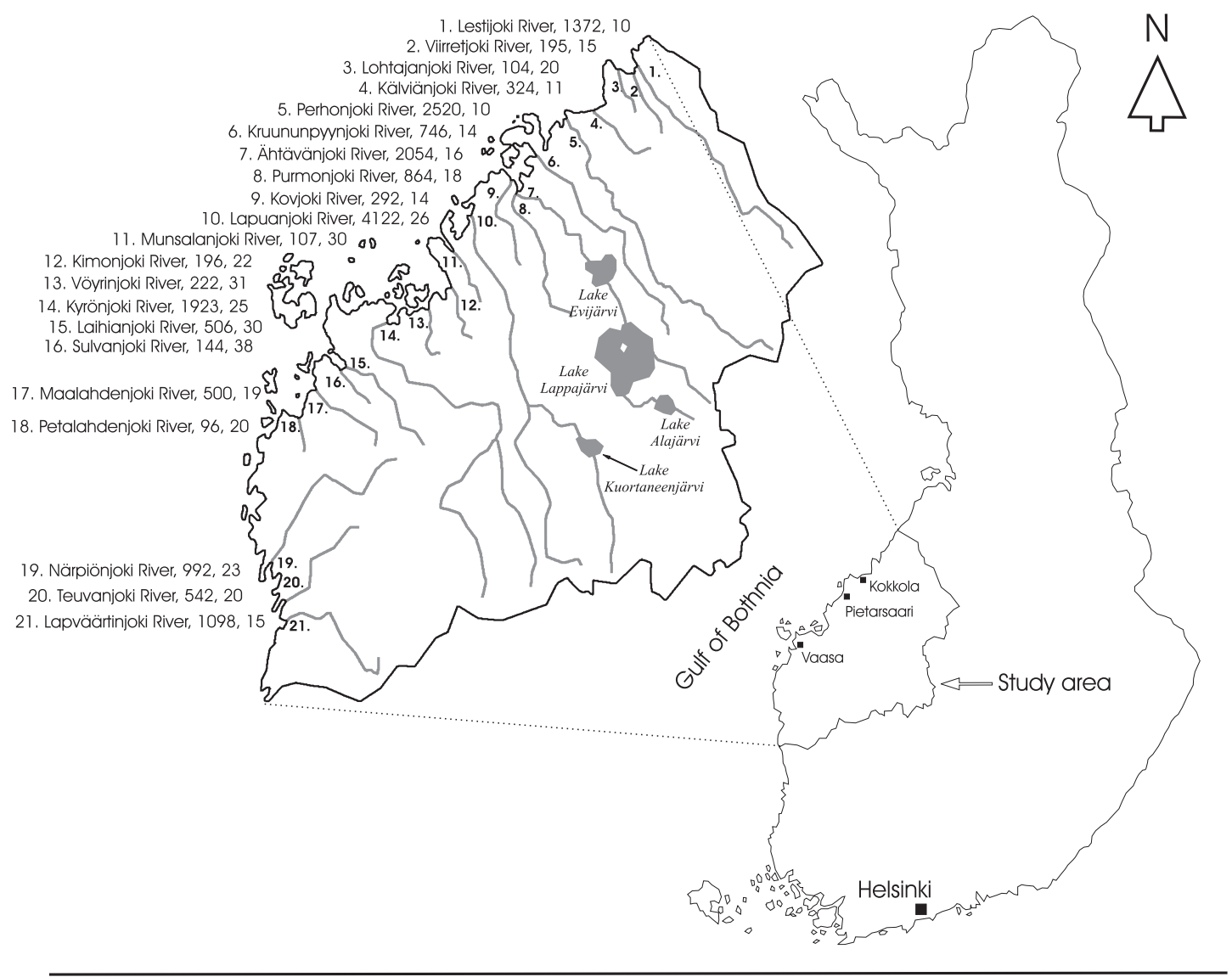

Fig. 1. The study area (acid sulphate soil hotspot area) in Western Finland. The names of the river are followed by catchment size $\left(\mathrm{km}^{2}\right)$ and share of arable land in the catchment area $(\%)$.

phy and land use as the others, one can assume that these rivers have a hydrograph similar to the ones measured. For such rivers the flow for each day was calculated according to the formula used by the West Finland Regional Environment Centre:

$$
1 / \mathrm{s}_{(\mathrm{X})}=1 / \mathrm{s}_{(\mathrm{Y})} / \mathrm{km}^{2}{ }_{(\mathrm{Y})} * \mathrm{~km}^{2}{ }_{(\mathrm{Z})}
$$

where " $\mathrm{X}$ " is the unmeasured river, " $\mathrm{Y}$ " is the closest river where a daily measurement was carried out and " $Z$ " is the drainage basin size of the unmeasured river.

\section{Water analyses}

At each sampling site on each sampling occasion, field measurements of $\mathrm{pH}$, electrical conductivity (EC) and temperature were carried out. Filtered ( $0.45 \mu \mathrm{m}$ membrane filter, Millipore HA) and acidified (ultra pure nitric acid; $\mathrm{pH}<2$ ) samples collected in polyethylene bottles were used for the determination of silver (Ag), $\mathrm{Al}$, arsenic (As), boron $(\mathrm{B})$, barium $(\mathrm{Ba})$, beryllium $(\mathrm{Be})$, bismuth (Bi), calcium $(\mathrm{Ca}), \mathrm{Cd}, \mathrm{Co}$, chromium $(\mathrm{Cr})$, copper 
Vol. 14 (2005): 24-33.

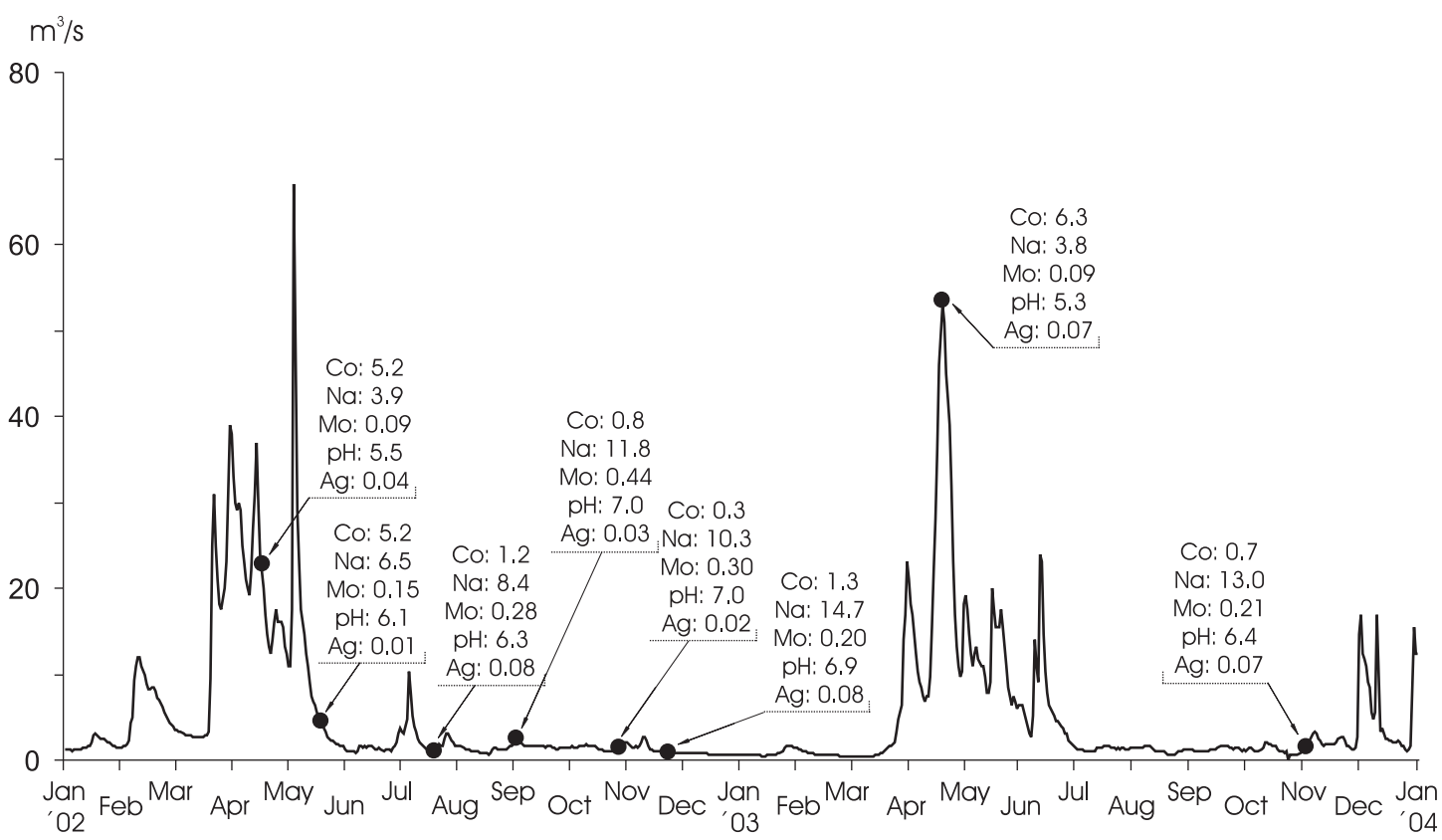

Fig. 2. Närpiönjoki River hydrograph for the time period 2002-2003, sampling events (marked with black circles), and concentrations for a representative variable for each group for every sampling event: Group A1: Co ( $\left.\mu \mathrm{g} 1^{-1}\right)$, Group A2: Na $\left(\mathrm{mg} \mathrm{l}^{-1}\right)$, Group A3: Mo $\left(\mu \mathrm{g} \mathrm{l^{-1 }}\right)$, Group B: $\mathrm{pH}$ and Group C: Ag $\left(\mu \mathrm{g} \mathrm{l^{-1 }}\right)$.

$(\mathrm{Cu})$, iron $(\mathrm{Fe})$, potassium $(\mathrm{K})$, lithium $(\mathrm{Li})$, magnesium $(\mathrm{Mg}), \mathrm{Mn}$, molybdenum (Mo), sodium $(\mathrm{Na})$, $\mathrm{Ni}$, phosphorus $(\mathrm{P})$, lead $(\mathrm{Pb})$, rubidium $(\mathrm{Rb})$, sulphur $(\mathrm{S})$, antimony $(\mathrm{Sb})$, silicon $(\mathrm{Si})$, strontium $(\mathrm{Sr})$, thorium (Th), Tl, uranium (U,) vanadium (V) and $\mathrm{Zn}$ with inductively coupled plasma-mass spectrometry (ICP-MS) at the commercially accredited chemical laboratory of the Geological Survey of Finland. Filtered $(0.45 \mu \mathrm{m}$ membrane filter Millipore HA) samples collected in polyethylene bottles were used for the determination of dissolved organic carbon (DOC) with a Shimadzu Total Organic Carbon 5050 analyzer (catalytic combustion).

\section{Area description}

Data on the size and land-use of the catchments (Fig. 1) was obtained from West Finland Regional Environment Centre. Acid sulphate soils are expected to occupy large areas under the agricultural land (up to 50\% according to Palko 1994), but their precise location and distribution is unknown. The areas not covered with agricultural land, are largely covered by forests underlain with till, peat and/or glaciofluvial material. The bedrock, which is dominated by Proterozoic granitoids and gneisses, outcrops only sporadically in the overall flat topography. Major cities are Kokkola, Pietarsaari and Vaasa and major industries emitting metals are UPM-Kymmene Pietarsaari Mills, OMG Kokkola Chemicals, Kokkola Kemira Industrial Chemicals and New Boliden Kokkola Zinc Oy.

\section{Results and discussion}

\section{Grouping of chemical elements, pH, DOC and $\mathrm{EC}$}

The percentage of arable land in the catchments correlated significantly (for $\mathrm{n}=21, \mathrm{P}<0.05$ for $\mathrm{r}_{\mathrm{s}}$ 
Roos, M. \& Åström, M. Hydrochemistry of rivers in an acid sulphate soil area

Table 1. Hydrochemistry of Sulvanjoki River (SR) and Lapväärtinjoki River (LR), corresponding groups and Spearman rank correlation for mean values in all 21 rivers versus $\%$ arable land in the catchments. (for $\mathrm{n}=21, \mathrm{P}<0.05$ for $\mathrm{r}_{\mathrm{s}}>0.44$ )

\begin{tabular}{|c|c|c|c|c|c|}
\hline Determinand & $\begin{array}{c}\mathrm{SR} \\
\text { mean }\end{array}$ & $\begin{array}{c}\mathrm{LR} \\
\text { mean }\end{array}$ & $\mathrm{SR} / \mathrm{LR}$ & Group & $\begin{array}{c}\% \text { Arable land } \\
\mathrm{r}_{\mathrm{s}}\end{array}$ \\
\hline Cobalt $\mu \mathrm{g}^{-1}$ & 26.0 & 0.52 & 50.5 & A1 & 0.65 \\
\hline Nickel $\mu \mathrm{g} \mathrm{l}^{-1}$ & 53.9 & 2.01 & 26.8 & A1 & 0.75 \\
\hline Manganese $\mu \mathrm{g} \mathrm{l}^{-1}$ & 1126 & 44.2 & 25.5 & $\mathrm{~A} 1$ & 0.59 \\
\hline Sulphur $\mathrm{mg} \mathrm{l}^{-1}$ & 53.1 & 2.55 & 20.8 & A1 & 0.59 \\
\hline Beryllium $\mu \mathrm{g}^{-1}$ & 1.43 & 0.07 & 19.6 & A1 & 0.68 \\
\hline Lithium $\mu g \mathrm{l}^{-1}$ & 63.8 & 3.26 & 19.6 & $\mathrm{~A} 1$ & 0.70 \\
\hline Sodium $\mathrm{mg} \mathrm{l}^{-1}$ & 66.0 & 4.62 & 14.3 & A2 & 0.69 \\
\hline Boron $\mu \mathrm{g}^{-1}$ & 178 & 13.5 & 13.1 & A1 & 0.66 \\
\hline Aluminium $\mu \mathrm{g} \mathrm{1^{-1 }}$ & 3104 & 311 & 10.0 & A1 & 0.61 \\
\hline $\mathrm{EC} \mu \mathrm{S} \mathrm{cm} \mathrm{cm}^{-1}$ & 663 & 67.6 & 9.8 & $\mathrm{~A} 2$ & 0.63 \\
\hline Magnesium mg ${ }^{-1}$ & 20.0 & 2.50 & 8.0 & $\mathrm{~A} 2$ & 0.64 \\
\hline Zink $\mu \mathrm{g}^{-1}$ & 119 & 15.3 & 7.8 & A1 & 0.68 \\
\hline Potassium mg $\mathrm{l}^{-1}$ & 10.7 & 1.56 & 6.9 & $\mathrm{~A} 2$ & 0.68 \\
\hline Strontium $\mu \mathrm{g}^{-1}$ & 189 & 36.2 & 5.2 & $\mathrm{~A} 2$ & 0.56 \\
\hline Calcium mg l-1 $^{-1}$ & 24.9 & 5.12 & 4.9 & A2 & 0.59 \\
\hline Rubidium $\mu \mathrm{g} \mathrm{l}^{-1}$ & 9.45 & 1.91 & 4.9 & $\mathrm{~A} 2$ & 0.54 \\
\hline Uranium $\mu \mathrm{g}^{-1}$ & 0.36 & 0.10 & 3.5 & A1 & 0.64 \\
\hline Cadmium $\mu \mathrm{g} \mathrm{l^{-1 }}$ & 0.39 & 0.12 & 3.3 & A1 & 0.63 \\
\hline Thorium $\mu \mathrm{g} \mathrm{l}^{-1}$ & 0.23 & 0.08 & 2.9 & A1 & 0.58 \\
\hline Silicon $\mathrm{mg} \mathrm{l}^{-1}$ & 9.80 & 3.77 & 2.6 & A1 & 0.49 \\
\hline Thallium $\mu \mathrm{g}^{-1}$ & 0.03 & 0.01 & 2.6 & A1 & 0.44 \\
\hline Copper $\mu \mathrm{g}^{-1}$ & 4.91 & 2.49 & 2.0 & A1 & 0.56 \\
\hline Barium $\mu \mathrm{g} \mathrm{l}^{-1}$ & 15.9 & 9.43 & 1.7 & $\mathrm{~B}$ & 0.33 \\
\hline Iron $\mathrm{mg} \mathrm{l}^{-1}$ & 1.13 & 0.77 & 1.5 & B & -0.15 \\
\hline Antimony $\mu \mathrm{g} \mathrm{l}^{-1}$ & 0.08 & 0.05 & 1.4 & B & 0.38 \\
\hline Silver $\mu \mathrm{g} \mathrm{l}^{-1}$ & 0.04 & 0.03 & 1.3 & $\mathrm{C}$ & -0.52 \\
\hline Cromium $\mu \mathrm{g} \mathrm{l}^{-1}$ & 1.46 & 1.14 & 1.3 & $\mathrm{~B}$ & -0.10 \\
\hline Phosphorus $\mu \mathrm{g}^{-1}$ & 40.2 & 32.0 & 1.3 & A3 & 0.49 \\
\hline DOC $\mathrm{mg} \mathrm{l}^{-1}$ & 17.8 & 13.8 & 1.3 & B & 0.08 \\
\hline Bismuth $\mu \mathrm{g} \mathrm{l}^{-1}$ & 0.05 & 0.05 & 1.0 & B & 0.01 \\
\hline Lead $\mu \mathrm{g} \mathrm{l}^{-1}$ & 0.57 & 0.60 & 0.9 & $\mathrm{~B}$ & 0.12 \\
\hline $\mathrm{pH}$ & 5.23 & 6.71 & 0.8 & B & -0.32 \\
\hline Arsenic $\mu \mathrm{g} \mathrm{l}^{-1}$ & 0.38 & 0.54 & 0.7 & $\mathrm{~B}$ & -0.19 \\
\hline Molybdenum $\mu \mathrm{g}^{-1}$ & 0.25 & 0.37 & 0.7 & A3 & 0.46 \\
\hline Vanadium $\mu \mathrm{g}^{-1}$ & 0.59 & 0.84 & 0.7 & $\mathrm{~B}$ & -0.29 \\
\hline
\end{tabular}

$>0.44)$ with the mean river-water concentrations (8 sampling events) of $\mathrm{Al}, \mathrm{B}, \mathrm{Be}, \mathrm{Ca}, \mathrm{Cd}, \mathrm{Co}, \mathrm{Cu}$, K, Li, Mg, Mn, Mo, Na, Ni, P, Rb, S, Si, Sr, Th, Tl, $\mathrm{U}, \mathrm{Zn}$ and EC. This group of elements is designated " $\mathrm{A}$ ", and is further divided on the basis of the pattern which can be concluded from the temporal variations and on the degree of enrichment in Sulvanjoki River compared to Lapväärtinjoki River. These two rivers were compared because the former is a known AS soils affected river while the latter is only marginally affected by these soils.
Group A1 are elements (Al, B, Be, Cd, Co, Cu, Li, $\mathrm{Mn}, \mathrm{Ni}, \mathrm{S}, \mathrm{Si}, \mathrm{Th}, \mathrm{Tl}, \mathrm{U}$, and $\mathrm{Zn}$ ) which were $>2$ times (up to 50 times) enriched in Sulvanjoki River as compared to Lapväärtinjoki River (Table 1 column 4) and which either occurred in highest concentrations when the flow was high (Al, B, Be, $\mathrm{Co}, \mathrm{Ni}, \mathrm{Tl}, \mathrm{U}$ and $\mathrm{Zn}$ ) or were weakly but still positively correlated to flow $(\mathrm{Cd}, \mathrm{Cu}, \mathrm{Li}, \mathrm{Mn}, \mathrm{S}, \mathrm{Si}$ and Th) (Fig. 2). Group A2 are determinants (Ca, $\mathrm{EC}, \mathrm{K}, \mathrm{Mg}, \mathrm{Na}, \mathrm{Rb}$ and $\mathrm{Sr}$ ) which were between 4.9 and 14.3 times enriched in Sulvanjoki River 
Vol. 14 (2005): 24-33.

compared to Lapväärtinjoki River (Table 1) and which concentrations tended to increase when the flow decreased, i.e. a negative correlation to flow (Fig. 2). Group A3 are elements (Mo, P) which occurred in similar concentrations in Sulvanjoki River and Lapväärtinjoki River and correlated negatively with flow.

The percentage of arable land in the catchments correlated insignificantly (for $\mathrm{n}=21, \mathrm{P}>$ 0.05 for $\left.r_{s}<0.44\right)$ with the mean river-water concentrations (8 sampling events) of $\mathrm{As}, \mathrm{Ba}, \mathrm{Bi}, \mathrm{Cr}$, $\mathrm{DOC}, \mathrm{Fe}, \mathrm{Pb}, \mathrm{pH}, \mathrm{Sb}$, and $\mathrm{V}$. These determinants, referred to as group "B", were thus not enriched in runoff from arable land. The corresponding correlation was significantly negative for Ag (Table 1 column 5). This metal, for clarity referred to as group "C", was thus depleted in runoff from arable land.

\section{Behaviour of Group Al elements}

Previous studies have shown that the elements included in this group (see above and Table 1) are all commonly enriched in small streams and/or ditches draining AS soils and thus are abundantly leached from this soil type (Eden et al. 1999, Åström 2001b). There is thus no question, considering the patterns identified in this study, that their major source in the studied rivers are AS soils under agricultural land. There exists, however, a great variation in the relative drainage from these soils, shown e.g. by the fact that Co is 50 times enriched while $\mathrm{Cu}$ only 2 times enriched in Sulvanjoki River compared to Lapväärtinjoki River (Table 1).

The mechanism for liberation in the AS soils is weathering of sulphides (only $\mathrm{FeS}$ and $\mathrm{FeS}_{2}$ have been identified, but others can certainly exist, and all can contain metals such as $\mathrm{Co}, \mathrm{Cu}, \mathrm{Ni}, \mathrm{Mn}$ and $\mathrm{Zn}$ ) and silicates. The reason for the elevated concentrations of these elements during higher flows (Fig. 2) is because they, through weathering of sulphides and silicates, are enriched in the unsaturated soil during low flows (dry periods) and are leached from the soil during increased flows when the soils are flushed.
Additionally, to the flow, the concentration levels are likely to be affected by when the latest wash-out of the soils occurred (Palko 1994). The longer time the groundwater table is low the longer oxidation and weathering processes are allowed to continue, which results in increased deposits of mobile metals to be transported, during next rain episode, to the rivers. Normally, especially during longer time perspectives, negative correlations between flow and weathering product concentrations dominate, in other words, the concentrations are lower during higher flows. During higher flows the detention time is shorter and the contribution from weathering is therefore lower (Laudon et al. 2001). Therefore it is rather surprising that so many metals from AS soils showed a positive correlation with the later stages of a flow (high flow and falling limb). The highest concentrations are expected to occur during rising limb episodes, which we could not prove due to exceptionally dry autumns and low sampling frequency.

The Se concentrations were in most cases below the detection limit $\left(0.05 \mu \mathrm{g} \mathrm{l}^{-1}\right)$, and is therefore not included in Table 1. However, the concentrations were clearly increased in Sulvanjoki River during all sampling events (up to $2.34 \mu \mathrm{g} \mathrm{l}^{-1}$ ) and in Vöyrinjoki River during six out of eight sampling events (up to $0.96 \mathrm{\mu g}^{\mathrm{l}^{-1}}$ ), and the mean concentrations in these rivers were 1.10 and 0.53 respectively. It is most likely that the AS soils are the source for the elevated Se concentrations in these two rivers. Hence, also Se is placed in this group.

\section{Ranking of rivers based on toxic elements}

The rivers were ranked, on the basis of Group A1 elements which have a particularly high potential toxicity (Al, Be, Cd, Co, Cu, Mn, Ni, Th, Tl, U and $\mathrm{Zn}$ ), by first ranking the rivers for each element concentration (1-21) and then adding the eleven values obtained $(11$ elements $\times 21$ streams $=231$ point maximum / 11 point minimum). The results, shown in Fig. 3, indicate the ordering of the rivers from the ones carrying the highest to those carry- 
Roos, M. \& Åström, M. Hydrochemistry of rivers in an acid sulphate soil area

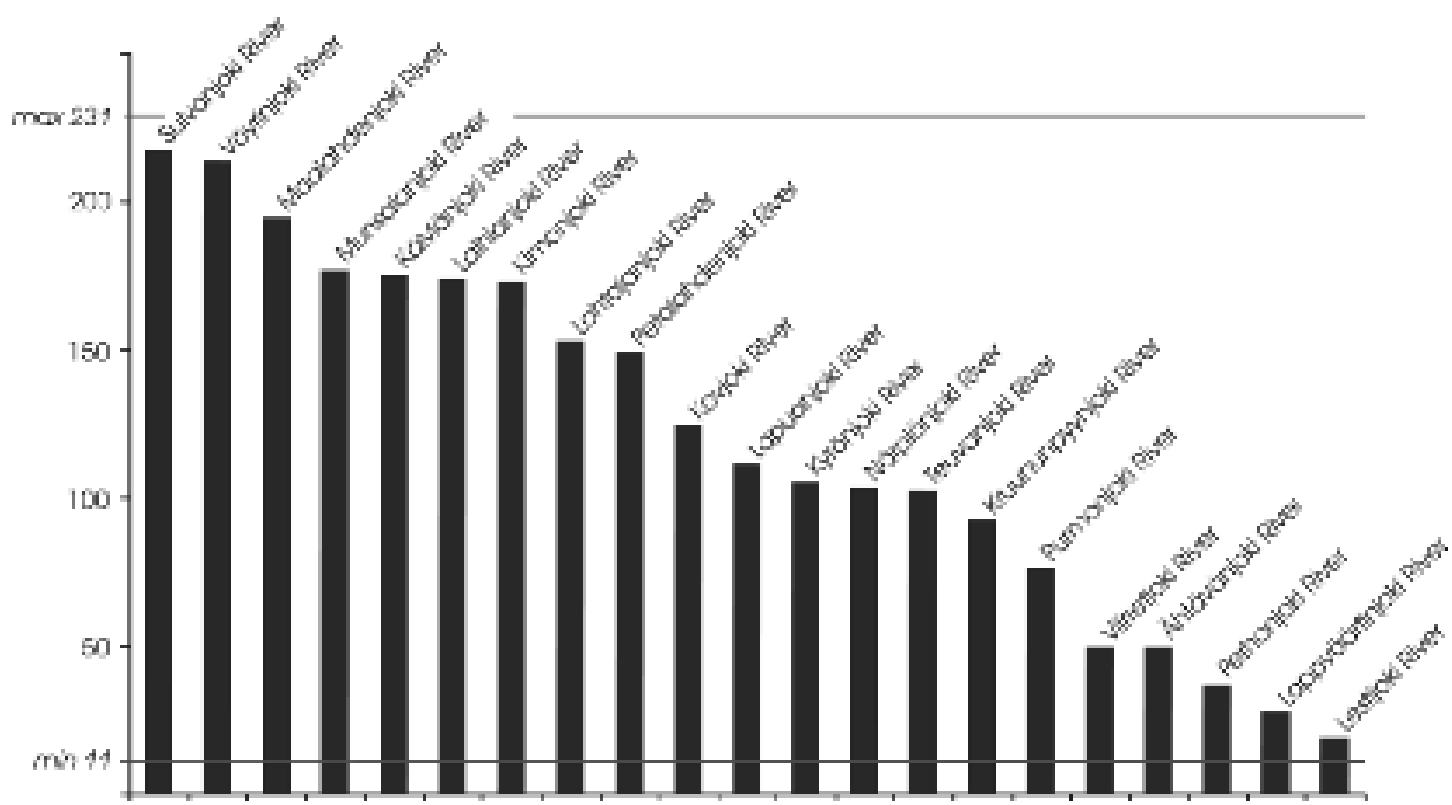

Fig. 3. River ranking based on the relative concentrations of potentially toxic metals in the waters $(\mathrm{Al}, \mathrm{Be}, \mathrm{Cd}, \mathrm{Co}, \mathrm{Cu}, \mathrm{Mn}$, $\mathrm{Ni}, \mathrm{Th}, \mathrm{Tl}, \mathrm{U}$ and $\mathrm{Zn}$ ). For explanation of mathematical procedure, see the text.

ing the lowest levels of potentially toxic metals leached from AS soils during the sampling events. In detail, Sulvanjoki (as expected) and Vöyrinjoki River had the highest loads, followed by Maalahdenjoki River and then another four on basically the same numbers, i.e. Munsalanjoki, Kälviänjoki, Laihinjoki and Kimonjoki Rivers. Lestijoki River had the lowest ranking, and another four rivers (Viirretjoki, Ähtävänjoki, Perhonjoki, Lapväärtinjoki) had overall low numbers. Of the large rivers (catchments areas $>1900$ $\mathrm{km}^{2}$ ), two had a low ranking (Perhonjoki and Ähtävänjoki), while the other two (Lapuanjoki and Kyrönjoki) had intermediate ranking which shows that also the larger rivers are affected. These results can be used: (1) as a starting point for environmental impact assessment of ongoing and future operations (e.g. drainage) in the catchment areas, (2) to show which rivers need marked attention with regards to the water framework directive (CEC 2000).

\section{Behaviour of Group A2 variables}

As the determinants of this group (see above and Table 1) were enriched in runoff from arable land, similar to the elements in Group A1, and because the sequence of elements here included have shown to drain from AS soils in earlier studies (Åström and Åström 1997, Eden et al. 1999, Åström and Spiro 2000), we can draw the conclusion that also these determinants originate from the AS soils. The mechanism for liberation is weathering of silicates, cation exchange and possibly mobilisation of salts in pore water. No chalcophilic (sulphide-bound) metals occurred in this group. The remarkable difference, from the ele- 
Vol. 14 (2005): 24-33.

ments in Group A1, is that these determinants tended to decrease with increasing flow (Fig. 2). The reason for this behaviour could be linked to the following two mechanisms: First, these elements are leached from arable land (AS soils) but during extreme low flow events these elements arrive, not in great quantities, but in high concentrations from deeper groundwater. This results in a negative correlation with flow, but does not exclude a discharge from AS soils. Second, dissolved ions/metals concentrate in AS soils through evaporation and weathering processes when the groundwater level is low, and during an increase in flow (rising limb) the excess of ions are drained, which is the moment when we can expect the highest concentrations in the river water. When the flow has reached high flow or is decreasing (falling limb) the surplus of ions have been already, to a large extent, drained from the soil which causes somewhat lower concentrations as a result of fewer ions but also due to the diluting effect caused by the ongoing high flow (Fölster and Wilander 2002). Thus, there is the possibility that the A2 elements have already been leached to a considerable extent during the sampled peak flows and falling limbs.

\section{Behaviour of Group A3 elements}

Since the elements in this group (Mo, P) were enriched in runoff from arable land but not in Sulvanjoki River (Table 1) they are drained from arable land more than from other types of land, but the source is not AS soil weathering. This is in line with earlier studies, which have shown that neither Mo nor $\mathrm{P}$ is particularly mobile in these soils (Åström 1998, Åström and Deng 2003). Possible source of P could therefore be anthropogenic spreading, e.g. fertilizing of arable land and also suspended soil material, eroded from arable land more abundantly than from other forms of land use. For both elements it seems that, besides the correlation with arable land, there is a clear tendency for higher concentrations in the more southern rivers than the rivers farther to the north. The percentage of arable land in the catchments is overall greater to the south which partly explains this regional pattern.

\section{Behaviour of Group B variables}

Since the determinants of this group (see above and Table 1) were not enriched in runoff from arable land they are not leached from AS soils in larger quantities than from other soil types. As a result of the latter, these determinants occurred in similar concentrations in both Sulvanjoki River and Lapväärtinjoki River (Table 1). This falls in line with other studies which show that these elements are not in general enriched in ditches draining AS soils (Åström and Åström 1997, Eden et al. 1999). The strong correlation of $\mathrm{pH}$ with the flow (Fig. 2) is a result of the following mechanisms: First, when flow through AS soils occurs, dissolved sulphates from the soil are transported in the form of sulphuric acid $\left(\mathrm{H}_{2} \mathrm{SO}_{4}\right)$ which in turn acidifies the rivers. Second, when flow through forest soil occurs, large quantities of DOC are transported and alkalinity decreases (Laudon and Bishop 1999, Bishop et al. 2000, Laudon et al. 2000), which acidifies forest waters. Consequently, when flow increases there is an increase of hydrogen ions in the water originating from both AS soils and humus rich forest soils. This causes the strong negative correlation between flow and $\mathrm{pH}$ in the rivers. During summer, in addition to low flow conditions, abundant algal growth causing carbon dioxide uptake during photosynthesis can force the $\mathrm{pH}$ to higher values. As a consequence of this, in line with Lahermo et al. (1996), Roos and Åström (2005) and Åström and Spiro (2005), the AS soils have a smaller effect on $\mathrm{pH}$ than on many other elements (see above) in river waters. This is controversial, since the general belief is that AS soils affect, in particular, the $\mathrm{pH}$ of the waters.

For the remaining determinants the following possibilities exist: First, they are not bound to sulphides or easily weathered silicates in the AS soils, which however certainly is not the case for $\mathrm{Fe}$ which occurs abundantly as sulphide or oxide depending on the redox conditions or second, they are immobile in the AS soils and thus not leached. However, other interesting spatial patterns and features existed for several elements. The concentrations of $\mathrm{Fe}$ in general increased from south to north. The solubility of this metal increases as $\mathrm{pH}$ 
decreases and it forms strong complexes with organic compounds. However, the spatial Fe pattern was not correlated with that of $\mathrm{pH}$ or DOC. Therefore, it seems likely that in the catchments further north, for some reason, reduced Fe enters the rivers more abundantly than in those in the south. Another example is $\mathrm{Sb}$, which in Kyrönjoki River during seven of the eight sampling events occurred in the highest concentrations of the entire study, and had mean concentrations two or more times higher than for any other river. Since this is a potentially toxic element, however not occurring in toxic concentrations in the dataset of this study, its sources and pathways in Kyrönjoki River deserves further attention.

The DOC in the rivers is dominated by humic substances derived from forest land and mires. From the AS soils, DOC is leached only to a small extent. This has also been shown in other studies (Åström 2001b), and is most likely explained by sorption of humic substances on the abundant Fe hydroxides found throughout the AS soil profile.

\section{Behaviour of Group C element}

Silver correlated, as the only element, negatively with percentage arable land (Table 1), which shows that this metal either is depleted in runoff from arable land or enriched in runoff from forest land. In addition, eight of the nine northernmost rivers had a higher mean Ag concentration than the rest of the rivers, and during the third sampling run (Summer 2002) the mean Ag concentration was four times higher than during the seven other sampling events. The reasons for these patterns are unknown.

\section{Conclusions}

The study show that AS soil leaching has a considerable impact on the rivers in the AS soil hotspot area of western Finland. Of the 35 variables determined in the river waters, as many as 24 were shown to be abundantly leached from these soils.
A river ranking based on 11 potentially toxic metals (Al, Be, Cd, Co, Cu, Mn, Ni, Th, Tl, U and Zn), leached from AS soils was carried out. The results showed that Sulvanjoki River, Vöyrinjoki River and Maalahdenjoki River had the highest levels of these metals, and that Lestijoki River, Lapväärtinjoki River and Perhonjoki River had the lowest. This information can be used for a number of environmental protection and planning purposes. Other determinants were not related to AS soil occurrence ( $\mathrm{As}, \mathrm{Ba}, \mathrm{Bi}, \mathrm{Cr}, \mathrm{DOC}, \mathrm{Fe}, \mathrm{Pb}, \mathrm{pH}, \mathrm{Sb}$, and $\mathrm{V})$, or even decreased as the proportion of arable land (and thus AS soil cover) increased (Ag).

The highlighted area is quite level, and the land rise following the latest ice age is somewhat greater, for most rivers, at the outlet than headwater. This causes the rivers to silt up and the need for dredging have become greater. After the completion of the sampling for this study, it has been decided that Vöyrinjoki River is to be dredged along a ca. $20 \mathrm{~km}$ distance. Silt is to be excavated along the river, and the main stem will be deepened. The heaps of silt are to be placed on adjacent fields. Considering the high metal levels in the water of this river and the high metal concentrations in the sediments outside its mouth (ongoing studies), let this be a warning for such an activity. While the dredging certainly is necessary from a hydrological point of view, there is every reason to believe that the silt to be excavated will contain (very) high contents of many potentially toxic metals. We therefore suggest a thorough environmental risk assessment of the material to be excavated from that river.

Acknowledgements. This study was financially supported by Svenska litteratursällskapet i Finland r.f (Ingrid, Margit och Henrik Höijers donationsfond II), Åbo Akademis Jubileumsfond 1968, K.H. Renlunds stiftelse, Ella och Georg Ehrnrooths stiftelse and Maa- ja Vesitekniikan Tuki Ry. We thank Nina Granholm at the Laboratory of Wood and Paper Chemistry for the DOC analyses. Karl-Erik Storberg at West Finland Regional Environment Centre was kind in providing information regarding the studied catchments. 
Vol. 14 (2005): 24-33.

\section{References}

Åström, M. 1998. Mobility of Al, P and alkali and alkaline earth metals in acid sulphate soils in Finland. The Science of the Total Environment 215: 19-30.

Åström, M. 2001a. Effect of widespread severely acidic soils on spatial features and abundance of trace elements in streams. Journal of Geochemical Exploration 73: 181-191.

Åström, M. 2001b. The effect of acid soil leaching on trace element abundance in a medium-sized stream, W. Finland. Applied Geochemistry 16: 387-396.

Åström, M. \& Åström, J. 1997. Geochemistry of stream water in a catchment in Finland affected by sulphidic fine sediments. Applied Geochemistry 12: 593-605.

Åström, M. \& Deng, H. 2003. Assessment of the mobility of trace elements in acidic soils using soil and stream geochemical data. Geochemistry - exploration, environment, analysis 3: 197-203.

Åström, M. \& Spiro, B. 2000. Impact of isostatic uplift and ditching of sulphidic sediments on the hydrochemistry of major and trace elements and sulphur isotope ratios in streams, Western Finland. Environmental Science and Technology 34: 1182-1188.

Åström, M. \& Spiro, B. 2005. Sources of acidity and metals in a stream draining acid sulphate soil, till and peat, western Finland, revealed by a hydrochemical and sulphur isotope study. Agricultural and Food Science 14: 34-43.

Bishop, K., Laudon, H. \& Köhler, S. 2000. Separating the natural and anthropogenic components of spring flood $\mathrm{pH}$ decline: A method for areas that are not chronically acidified. Water Resources Research 36: 1873-1884.

CEC 2000. Directive of the European Parliament and of the Council establishing a framework for community action in the field of water policy. Official Journal L327/47.

Dent, D. 1980. Acid sulphate soils: morphology and prediction. Journal of Soil Science 31: 87-99.

Eden, P., Weppling, K. \& Jokela, S. 1999. Natural and landuse induced load of acidity, metals, humus and suspended matter in Lestijoki, a river in western Finland. Boreal Environment Research 4: 31-43.

Fölster, J. \& Wilander, A. 2002. Förändringar i vattenkemin i svenska vattendrag under 30 år. Sveriges lantbruksuniversitet, Institutionen för miljöanalys. Rapport 2002: 21. $30 \mathrm{p}$.

Hudd, R. 2000. Springtime episodic acidification as a regulatory factor of estuary spawning fish recruitment. Ph.D-theses. University of Helsinki, Finland.

Kjellman, J. \& Hudd, R. 1996. Changed length-at-age of burbot, Lota lota, from an acidified estuary in Gulf of Bothnia. Environmental Biology of Fishes 45: 65-73.

Lahermo, P., Väänänen, P., Tarvainen, T., Salminen, R., 1996. Geochemical atlas of Finland, part 3. Environmental geochemistry - stream waters and sediments. Geological Survey of Finland, Esbo, Finland. 149 p.
Laudon, H. \& Bishop, K.H. 1999. Quantifying source of acid neutralisation capacity depression during spring flood episodes in northern Sweden. Environmental Pollution 105: 427-435.

Laudon, H., Westling, O. \& Bishop, K. 2000. Cause of pH decline in stream water during spring melt runoff in northern Sweden. Canadian Journal of Fisheries and Aquatic Sciences 57: 1888-1900.

Laudon, H., Westling, O., Löfgren, S. \& Bishop, K. 2001. Modeling preindustrial $\mathrm{ANC}$ and $\mathrm{pH}$ during the spring flood in northern Sweden. Biogeochemistry 54: 171195.

Lowson, R.T. 1982. Aqueous oxidation of pyrite by molecular oxygen. Chemical Reviews 82: 461-497.

Palko, J. \& Yli-Halla, M. 1993. Assessment and management of acidity release upon drainage of acid sulphate soils in Finland. In: Dent, D.L. \& van Mensvoort, M.E.F (eds.). Selected papers of the Ho Chi Minh City symposium on acid sulphate soils. International Institute for Land Reclamation and Improvement Publication 53. p. 411-418.

Palko, J. 1994. Acid sulphate soils and their agricultural and environmental problems in Finland. Acta Universitatis Ouluensis, series $C$, technica $75.58 \mathrm{p}$.

Purokoski, P. 1959. Mapping of sulphur-rich sediments in coastal areas of Finland. Agrogeological Publications 74: 7-23. (In Finnish).

Ritsema, C.J., van Mensvoort, M.E.F., Dent, D.L., Tan, Y., van den Bosch, H. \& van Wijk A.L.M. 2000. Acid sulfate soils. In: Sumner, M.E. (ed.). Handbook of soils science, CRC Press. p. 121-154 (sect. G).

Roos, M. \& Åström, M. 2005. Seasonal and spatial variations in major and trace elements in a regulated Boreal river (Esse River) affected by acid sulphate soils. River Research and Application 21:351-361.

Sundström, R., Åström, M. \& Österholm, P. 2002. Comparison of the metal content in acid sulphate soil runoff and industrial effluents in Finland. Environmental Science and Technology 36: 4269-4272.

van Breemen, N. 1973. Soil forming processes in acid sulphate soils. In: Dost, H. (ed.). Acid sulphate soils, Proceedings of the international symposium on acid sulphate soils. International Institute for Land Reclamation and Improvement Publication 18. p. 66-130.

Weppling, K. 1993. Hydrochemical factors affecting the neutralization demand in acid sulphate waters. Vatten 49: $161-170$

Wiklander, L., Hallgren, G. \& Jonsson, E. 1950. Studies on gyttja soils: rate of sulfur oxidation. The Annals of the Royal Agricultural College of Sweden 17: 425-440.

Yli-Halla, M., Puustinen, M. \& Koskiaho, J. 1999. Area of cultivated acid sulfate soils in Finland. Soil Use and Management 15: 62-67. 